\title{
UGT1A7 wt Allele
}

National Cancer Institute

\section{Source}

National Cancer Institute. UGT1A7 wt Allele. NCI Thesaurus. Code C104105.

Human UGT 1A7 wild-type allele is located in the vicinity of 2 q37 and is approximately 91 $\mathrm{kb}$ in length. This allele, which encodes UDP-glucuronosyltransferase 1-7 protein, is involved in the metabolism of drugs and xenobiotics. Variation of the gene is associated with decreased metabolic activity. 